\title{
THE ASSESSMENT OF THE COMPLETENESS OF EDUCATIONAL CONTENT USING THE EXAMPLE OF TECHNICAL SUBJECTS
}

\author{
Jitka PLISCHKE - Jiř́ KROPÁC̆
}

\begin{abstract}
The text deals with the completeness of educational content, analyzes this concept especially in technical subjects. The focus of the text points to the assessment of completeness of the educational content, the possible considerations and requirements in terms of educational experience and current educational theories.
\end{abstract}

Key words: Completeness, educational content, technical subjects, Maslow's Hierarchy of Needs

\section{POSOUZENÍ ÚPLNOSTI VZDĚLÁVACÍHO OBSAHU NA PŘÍKLADU TECHNICKÝCH P̌̌EDMĚTŮ}

Resumé: Text se zabývá úplností vzdělávacího obsahu, analyzuje tento pojem především $\mathrm{v}$ technických předmětech. Těžiště textu je věnováno posouzení úplnosti vzdělávacího obsahu, možnými hledisky a požadavky z hlediska vzdělávací praxe i současných pedagogických teorií.

Klíčová slova: úplnost, vzdělávací obsah, technické předměty, Maslowova hierarchie potřeb

\section{1 Úvod}

Slovo úplnost je v zahraničních pedagogikách $\mathrm{v}$ př́islušném jazyce použiváno ve více významech. Lze se o tom snadno přesvědčit, zadá-li se např. „Ganzheitlichkeit Pädagogik“ do vyhledávače. V němčině je termín spojován zejména se jménem J. H. Pestalozzi, s jeho ideou sepětí učení $\mathrm{s}$ hlavou, srdcem, rukou. V podobném smyslu shledávala potřebu úplnosti i reformní pedagogika. Další výklady termínu záleží na různých př́stupech jednotlivých oborů.

V. Kulič $(1$, s. 7, 16) dává ,úplné řízení do souvislosti s adjektivy poučené ř́zení, popř. také dobře řízené učení (,dobře či úplně řízeného učení“ - s. 16). Toto chápání slova úplnost je pro nás návodné, ovšem $\mathrm{v}$ této stati je pohled na úplnost zaměřen didakticky, s důrazem na koncipování obsahu výuky, především výuky technicky zaměřených předmětů na základní škole. Zde úplnost či komplexnost vzdělávacího obsahu vyjadřuje požadavek, aby volba a způsob jeho zpracování vytvářely předpoklady pro naplnění „poslání“ výuky. Pojem vzdělávací obsah jsme převzali od J. Skalkové (2, s. 63 a dále). Jde tedy o:

- volbu vzdělávacího obsahu v rozsahu a hloubce zajišt'ující připravenost na zvládnutí reality,

- zpracování vzdělávacího obsahu do podoby přriměřeně náročného učiva umožňujícího osvojení žákovou aktivní a tvořivou činností, rozvíjející jeho myšlení (uspořádání učiva z hlediska potřeb učení žáka).
Rámcové vzdělávací programy pro základní vzdělávání (především pak pro sekundární vzdělávání) formulují široce pojaté vzdělávací výstupy a rámcově vymezují „méně konkretizované učivo“. To má mnohá pozitiva, ale ze strany realizátorů vzdělávání vyžaduje zvýšenou pozornost věnovanou úplnosti a následně i ucelenosti (integrovanosti, popř. systematičnosti) obsahu vzdělávání, při koncipování i př́i realizaci vzdělávání. Je prokazatelné, že z věd či oborů lze př́mo odvodit vzdělávací obsah a posoudit jeho úplnost jen výjimečně, a to $\mathrm{i}$ pro vyšší sekundární vzdělávání. Pro technické vzdělávání na sekundárním stupni, zohledňující řadu oblastí činností s technikou, toto platí zvýšenou měrou. Pro obecně technické vzdělávání nemůže být pro tvorbu vzdělávacího obsahu prrímo použita ani tzv. všeobecná technologie $(3$, s. 8); Allgemeine Technologie je známá v německy mluvících zemích i jinde z prací $\mathrm{H}$. Wolffgramma (4), (5).

Je zřejmé, že precizně vyjádřit význam termínu „úplnost vzdělávacího obsahu“ je nesnadné, zrovna tak konstatovat jeho dosažení u sekundárního vzdělávání všeobecně i odborně zaměřeného. Pojem úplnost $\mathrm{v}$ této souvislosti je považován za nedefinovatelný (F. Krüger). Snáze lze, zejména $\mathrm{v}$ konkrétním prípadě, formulovat negaci, tedy co vzdělávacímu obsahu chybí, aby následné učení žáka bylo po žádoucím doplnění obsahu možno považovat za úplné. I tak nacházíme řadu souvisejících otázek, na něž 
může být poskytnuta jen nejednoznačná odpověd'. Jsou to např́klad tyto skupiny otázek:

- Kdy je vhodnější postupné probírání „,teorií věd“, jejichž aplikace má význam pro pochopení a zvládnutí reality? Kdy je vhodnější zaměření na oblasti reality či témata přímo významná pro budoucí život žáka? Kdy je či kdy má být preferován vzdělávací encyklopedismus, formalismus, exemplarismus (6, s. 49-50)? $\mathrm{Na}$ čem závisí zastoupení kultivační funkce vzdělávání (vzdělávací subjektivismus) nebo vytváření kompetencí prímo souvisejících s uplatněním $\mathrm{v}$ životě či profesi (vzdělávací objektivismus), podrobněji dále, viz (7, s. 25)?

- $\mathrm{Na}$ základě čeho a jakým způsobem je formulováno poslání vzdělávacích oblastí v realizované výuce? Nakolik je to rámcovými vzdělávacími programy, názory a potřebami klientů školy, podmínkami školy a názory učitelů? Proč (a čím) se učební plány a tematické plány na obdobných školách liší? Jak stanovit patřičný rozsah vzdělávacího obsahu a hloubku jeho výuky ve vyučovacích předmětech, viz výše?

- Na čem závisí uplatňování preferencí jednotlivých funkcí vzdělávání (jde o informativní, formativní, instrumentální, výchovnou funkci), nakolik zde záleží na vyučovacím stylu učitele?

$\mathrm{V}$ didaktice se hojně setkáváme s aktivitami zaměřenými na pojem integrace výsledků vzdělávání, který znamená ucelení či scelení, viz mj. (8). Dosahování úplnosti vzdělávacího obsahu není systematicky zpracováno. Vnímání míry úplnosti vzdělávacího obsahu a snaha po jejím dosahování jakožto ,ideálního stavu“ však může vést mj. knapravení některých jednostranných vzdělávacích koncepcí, majících kořeny $\mathrm{v}$ zúženém vzdělávacím obsahu a následné nevhodné procesní stránce vzdělávání. Připomeňme řemeslné pojetí výuky technických prací na Ž̌ v minulosti. Podle našeho názoru podobně jako pojem úplnost také pojem kompetence nebyl dř́ve plně teoreticky rozpracován (9), přesto byl a je v pedagogické teorii i vzdělávací praxi bohatě a opodstatněně využíván. Dějiny techniky ostatně nabízejí mnoho prŕikladů praktického využívání teoreticky plně nepopsaných postupů i objektů.

Dosud jsme se věnovali především postupům a jejich souvislostem vedoucím kúplnosti vzdělávacího obsahu, v rámci těchto uváděných postupů jsou již kritéria posuzování úplnosti odvoditelná. Dále uvedeme vybrané př́stupy či aplikace pedagogické teorie, které mají k vymezení kritérií na posouzení úplnosti vzdělávacího obsahu přímý vliv.

Učitelé běžně reflektují nově vznikající požadavky, které jsou stavěny před školu a školní vzdělávání. V poslední době se široce vyskytují požadavky na - rozvoj finanční gramotnosti žáků, jejich schopnost zdravě žít, schopnost bránit se kyberstalkingu, volbu technických profesí atp. Tyto a další požadavky učitelé zohledňují ve výuce, činí to jejich výuku úplnou, užitečnou, aktuální. V dalším textu si povšimneme dvou méně běžných přístupů, s nimiž jsme se setkali v zahraniční odborné literatuře.

Záměrem stati je předložit $\mathrm{k}$ diskusi vybrané postupy a hlediska či kritéria posouzení úplnosti vzdělávacího obsahu na př́kladu výuky technických předmětů se zaměřením na jejich výuku na základní škole.

\section{Posouzení úplnosti vzdělávacího obsahu}

$V$ predchozím textu jsme upozornili na význam propojení (a podmíněnost),,statické stránky“ vzdělávání, ve výuce představované především zpracováním vzdělávacího obsahu v učivu, s „dynamickou“, procesní stránkou vzdělávání či výuky. J. Slavík a T. Janík (10) považují za obsah výuky všechno, co žák může: a) pamatovat si (vybavit si), b) v mysli nebo ve skutečnosti používat, vytvářet, přetvářet, c) sdělovat, d) uvažovat, e) čím může být ovlivněn v prožívání, myšlení, jednání, postojích. Jde nám, obdobně jako $\mathrm{v}$ tomto vymezení provedeném J. Slavíkem a T. Janíkem, o sepětí převážně statických znalostí přímo odrážejících jejich prezentaci učivem či texty (vím že), se způsobilostí je používat na základě rozvinutého myšlení (vím jak a kdy co). Způsobilost užít znalosti pochopitelně vzniká až v procedurách vzdělávání či výuky, jež jsou ale podmíněné způsobem prezentace učiva i dalšími podmínkami (vybavením). Nabízející se termín úplnost výuky chápeme jako název širšího pojmu, zacíleného však na konkrétní výuku a její výsledky.

Posouzení (evaluace) úplnosti vzdělávacího obsahu či obsahu výuky, viz předchozí odstavec, je při šíři tohoto pojmu náročné. V současnosti lze očekávat, že bude nejčastěji probíhat v rámci instituce poskytující sekundární vzdělávání, zejména při vytváření (školních) vzdělávacích programů a jejich evaluaci. Dle zkušeností získaných v Polsku (odkazováno je i na zkušenosti USA) je úspěšné vypracování a zavádění vzdělávacího programu do života 
školy i zajištění kvality vzdělávání podmíněno vnějšími i vnitřními evaluacemi (11).

Přijměme analogii mezi postupy posouzení úplnosti vzdělávacího obsahu a postupy evaluace vzdělávacích programů, ty však zahrnují i další hlediska (např. prověrení správnosti rozhodnutí, okolností spojených se zaváděním vzdělávacích programů, shody programu a způsobu jeho realizace, vlivu nepředpokládaných okolností atp.). Evaluace vzdělávacího programu a jeho zavádění, včetně posouzení úplnosti vzdělávacího obsahu, může být dle (12) prováděna ve třech etapách:

1. evaluace předempirická - při a po vypracování projektu vzdělávacího programu; činnosti mají charakter předempirických analýz prováděných experty (logická analýza konstrukce programu, analýza souladu výběru obsahu, metod a organizačních řešení s cíli, hypotetická analýza z hlediska žáka i sondáž mezi učiteli),

2. evaluace formativní, viz rovněž (13, s. 293), je prováděna $v$ průběhu zkušebního zavádění programu, je prováděna např. ,zkouška“ s malou skupinou žáků, v přirozených podmínkách, má spíš dílčí charakter,

3. sumativní evaluace shrnující program a jeho zavádění jako celek, hodnotící program na základě vzdělávacích výsledků, je mj. sledováno i uplatnění absolventů atp.

Evaluace s pokračujícím zaváděním programu (od 1. do 3. etapy) přechází od kvalitativní ke kvantitativní. Podle našeho názoru lze při posuzování úplnosti vzdělávacího obsahu nejčastěji očekávat postupy odpovídající první etapě, tam i pro další etapy je důležitá otázka vyjádření hledisek a požadavků na úplnost vzdělávacího obsahu, které mohou vést $\mathrm{k}$ formulaci uchopitelných kritérí pro posuzovatele/posouzení úplnosti.

Autoevaluací školy se podrobněji zabývá D. Nezvalová (14, s. 49-84), včetně oblastí kurikula a výsledků (1. a 2. oblast). Problémem úplnosti vzdělávacího obsahu se přímo nezabývá, pro naše záměry je důležité zdůraznění mj. významu vize školy i charakteristik učících se, v souladu s touto autorkou lze aplikovat návrh metod evaluace i vymezení respondentů (zdrojů informací).

\section{Vybraná hlediska a požadavky na úplnost vzdělávacího obsahu technických př̀edmětů}

- soudobé problémy vzdělávací praxe

Požadavky na úplnost vzdělávacího obsahu mohou být odvozovány $\mathrm{z}$ hlediska potřeby spojení:
- rozvíjení či kultivace žákova vnitřního světa, tedy jeho vědomí, prožívání, bytí; zde jde podle B. Blížkovského (7, s. 25) o pedagogický subjektivismus,

- se žákovou potřebou být připraven na požadavky vznikající při situacích spojených s technikou, tedy na zvládání vnějšího světa a makrosvěta, vč. technického a profesního, zde jde o pedagogický objektivismus (7, s. 25).

Jde o propojení hledisek vnitřního a vnějšího světa žáka, ne o jejich kladení „proti sobě“. Také v technickém sekundárním vzdělávání probíhá presun od pojetí transmisivního (zde mj. řemeslného, úzce návodného, s nízkým využitím myšlenkové aktivity) $\mathrm{k}$ pojetí konstruktivistickému, jež vychází z motivované činnosti žáků zacílené významně na rozvoj jejich vnitřního světa, myšlení, tvořivosti, respektující žákovy danosti a dosavadní zkušenosti.

Obecně technické předměty mají pro výběr a prezentaci obsahu výuky řadu dalších hledisek. Je třeba mj. respektovat zájmy žáků a informovat je o potřebném technickém obsahu, který je ale zajímá; souvisí to s jejich motivací. Rostou i požadavky na rozvoj vychovanosti žáka a vytváření „obecně uznávaných“ postojů, podrobněji (15). Velmi často se však, i při vnějšś aktivní činnosti žáků v technickém vzdělávání na ZŠ, setkáváme $\mathrm{s}$ nedoceněním využívání znalostí $\mathrm{z}$ technických a jiných vyučovacích předmětů, žáci pracují mechanicky, „bezmyšlenkovitě“, tím je výuka neúplná. Jde o nedodržení didaktické zásady uvědomělosti. Kompetence se proto jeví jako „vhodná forma“ popisu vzdělávacích záměrů, nebot' vyjadřuje či vyžaduje organické propojení znalostí, dovedností a hodnotové orientace.

Kromě změn procesní stránky výuky technických předmětů $\mathrm{v}$ nižším sekundárním vzdělávání jsou nejen v České republice zřetelné změny obsahu výuky, dnes zaměřené především uživatelsky (na ZŠ mj. péče o domácnost) a na moderní oblasti techniky (mobilní telefony); tím dochází ke zvýšení úplnosti vzdělávacího obsahu.

Odborné technické předměty naplňují požadavek úplnosti především ve vztahu k poskytované profesní připravenosti, popř. zdokonalení - zda absolvent dobře umí vše to, co po něm při výkonu profesí může být žádáno, co by mohl potřebovat. Předchozí větu je třeba chápat nezúženě a k požadavku na odborné vzdělání organicky zahrnout požadavky na všeobecné vzdělání, včetně technického vzdělání obecnějšího než profesního; uvedené je ve 
středním odborném vzdělávání žákům poskytováno.

Lze shrnout - výrazným rysem obsahu technického vzdělávání, odborného i všeobecného, je trvalá potřeba významné inovace jejich obsahové a procesní stránky. Tyto inovace zahrnující celkovou strategii výuky, jsou reakcí na trvale se zvyšující využívání techniky v běžných profesních a životních situacích a na její současný rychlý rozvoj. Tyto vzdělávací požadavky představují i požadavky na úplnost vzdělávacího obsahu; cenná je tedy nabídka pedagogických teorií nabízejících způsoby a postupy, jak tyto situace dobře řešit. V následujícím textu si povšimneme některých $\mathrm{z}$ nich.

\section{- vybraná nabídka soudobých teorii pedagogiky}

Při úsilí o úplnost vzdělávacího obsahu pro technické vzdělávání je podle našeho názoru významné aplikovat poznatky související s pojmem technické myšlení a pro základní školy související s pojmem technická gramotnost. Tyto pojmy v obecné rovině představují také předjímané výsledky vzdělávání. Jinak řečeno, je vhodné pohlížet na obsah a průběh výuky technických předmětů zhlediska rozvoje technické gramotnosti/technického myšlení/popř. i prípravy na profesi, to poslední především v odborném vzdělávání.

I. Krušpán (16) přeložil výstižnou charakteristiku pojmu technické myšlení formulovanou polským psychologem E. Franusem. Tento psycholog upozornil, že technické myšlení má dvě související stránky - procesy poznávací, které mají charakter převážně analytický a směřují $\mathrm{k}$ zobecnění poznání, popř. k teorii, a procesy konstrukce, $\mathrm{v}$ nichž převažuje syntéza a směřují $\mathrm{k}$ realizaci, aplikaci poznaného, k praxi. Pojem technické myšlení tedy označuje především určitou kvalitu, zaměření, obsah myšlení jedince, může být vyjádřena jeho různá úroveň. Podrobně jsme se problematikou technického myšlení zabývali v (6, s. 22-31).

Technická gramotnost je u nás chápána v podstatě jako technické vzdělanostní minimum, jako základní míra technického myšlení, kterou by si měl osvojit každý jedinec, jejíž překročení je nezbytné pro život $\mathrm{v}$ současné společnosti (závisí tedy na soudobých požadavcích společnosti). Měla by proto být dosažena nejpozději na konci základní školy. Obecné členění požadavků na dosažení technické gramotnosti v souladu s M. Dyrenfurthem, který jako první rozpracoval tento pojem, formuloval J. Stoffa (17). Jde o základní způsobilosti $\mathrm{v}$ těchto směrech:

- uvědomovat si klíčové procesy $\mathrm{v}$ technice (co to je a jak to funguje),

- obsluhovat technické př́stroje a zařízení,

- aplikovat technické poznatky $\mathrm{v}$ nových situacích,

- rozvíjet vlastní technické vědomosti, dovednosti a návyky,

- využívat technické informace a hodnotit je

Z hlediska záměrů stati jde o teoretickou bázi značně obecnou, nicméně usnadňující hledání způsobu posouzení ucelenosti vzdělávacího obsahu. Jde především o spojení poznávací, analytické složky se složkou syntetickou, aplikační, o jejich optimální vzájemné zastoupení, propojení a způsob realizace odpovídající dalším pedagogickým, vzdělávacím i technickým požadavkům.

Úplnost vzdělávacího obsahu zohledňuje i postup didaktické transformace či tvorby vzdělávacího projektu, jak je popsaný A. Riedlem (18, s. 48). Př́prava projektu, představme si nejprve, že pro vzdělávání technikủ, je v první fázi zaměřena na vymezení situací a činností, které absolvent musí zvládat. V souladu s prací A. Riedla nazvěme výchozí rovinu těchto souboru jednání určených $\mathrm{k}$ didaktické transformaci jako I. soubor jednání určený k osvojení žákem (v originále Handlungsfelder). II. rovinu postupu didaktické transformace můžeme podle A. Riedla nazvat učební pole (Lernfelder). Jde o didakticky koncipované, $\mathrm{k}$ dalšímu zpracování pro výuku určené, uspořádané soubory požadavků či úloh, které navozují žádoucí činnost žáků vedoucí k osvojení zamýšleného jednání. III. rovinu postupu didaktické transformace jsou tzv. učební situace (Lernsituationen). Jde o konkretizaci či rozpracování předchozí roviny do situací, do nichž bude ve výuce uveden žák a $z$ nichž vyplynou požadavky na jeho učební činnost směřující k osvojení požadovaného (situací všestranně zajištěných mj. texty, pomůckami atd.).

Př́nos uvedeného postupu transformace pro úplnost vidíme kromě jím vnášené systematičnosti do vytváření vzdělávacích obsahů i ve využití zpětné vazby při posouzení výsledků transformace, nebot' ta nezbytně zahrnuje hledisko úplnosti. Zpětná vazba je 
prováděna jak mezi rovinami II učební pole - I soubor jednání určený k osvojení žákem, tak také mezi rovinami III učební situace - I soubor jednání určený k osvojení žákem. V prvním uvedeném př́ípadě jde o otázku, jak přispívaji (a zda dostatečně) jednotlivá vymezená učební pole k ovládnutí komplexní problematiky, popř k ovládnutí činností vymezených obecnými cíli výuky. Ve druhém prŕpadě je možno se ptát, jak přispívají jednotlivé učební situace ke zvládnutí požadované technické problematiky. Je zřejmé, že tento postup není aplikovatelný jen v odborném vzdělávání, ale i při koncipování jiného obsahu zaměřeného především na osvojování činností či dovedností a ve všeobecném technickém vzdělávání na základní škole.

V pojednání o technickém myšlení jsme upozornili, že má dvě stránky, stránku poznávací směřující spíš ke „vzniku teorie“, a stránku syntetickou směřující k praxi, $\mathrm{k}$ aplikaci. Je tedy třeba ve vzdělávacím obsahu $\mathrm{v}$ tomto smyslu propojovat obsah odrážející okruhy „pro žáka důležité" technické praxe, tyto okruhy jsou $\mathrm{v}$ celkovém kontextu výuky o technice většinou prioritního postavení, s obsahem zahrnujícím vybrané oblastí „upravené teorie“. Zvládání teorie přispívá ke kultivaci žákova vnitřního světa, poznávání, k rozvoji analytického, teoretického myšlení. Praxe představuje př́ležitost pro schopnosti aplikace a syntézy.

Ve vzdělávacím obsahu technických předmětů je v míře dané jejich zacílením odrážen ze „„rrí světů Karla Poppera" svět 1 (svět fyzického prostředí, techniky, př́rody ...) i svět 3 (svět výtvorů lidského ducha, vědy, kultury, umění ...), podrobněji (19). Osvojování vzdělávacího obsahu žákem vede k vytváření žákova subjektivního světa 2 .

Technické předměty v sekundárním vzdělávání jsou zaměřeny spíš na realizační praxi a na tím podmíněné zvládnutí teorie (jak jsme výše uvedli, praxe má „prioritu“). Proto v nich jde, v souladu s členěním podle S. Štecha $(20$, s. 110), o propojení vzdělávacího obsahu př́islušného kódu integrovanému, jenž je určující, $\mathrm{s}$ potřebným vzdělávacím obsahem príślušným kódu seriálnímu. V kódu integrovaném se uvažuje o tématech učiva, poznatky nejsou hierarchicky uspořádané, ale vázány $\mathrm{k}$ tématu, jsou tedy osvojovány $\mathrm{v}$ konkrétním kontextu. „Proto jsou vyučovací postupy i učivo extenzivní a prưřezové - jsou konstruovány tak, aby umožnily projít zkušeností s co největším počtem situací, kontextů, osob, míst atd.“(20, s. 110).
V kódu seriálním je učivo odvíjeno od poznání teoretického, vedoucího k obecnosti a systematičnosti. Probíhá „...rozlišování a tř́́dění kategorií jako jednotek majících vztahy k jiným jednotkám.“" (20, s. 109). Ve výuce jsou stanovovány vztahy mezi abstraktními významy, jak se děje při výuce odrážející teorie technických věd (technická mechanika, nauka o materiálech, technická grafika, teoretické základy elektrotechniky atp.). Tyto průřezové obsahy mají ve vzdělávacím obsahu zřetelně integrační význam.

V technickém vzdělávání prováděném na základní škole představují vybrané oblasti obsahu technické výchovy témata významná pro budoucí činnost žáků s technikou, dále pro žáky přitažlivá a disponující potencí rozvíjet osobnost. Představují vlastně výsledek volby vzdělávacího obsahu $\mathrm{v}$ integrovaném kódu. Jak může být, kromě volby vhodných témat, viz výše, dosahována úplnost obsahu $\mathrm{v}$ tomto kódu? Především popsaným umožněním zobecnění konkrétních situací a to zejména jejich propojením s teorií (seriální kód). Dále může být úplnost zvyšována doceněním systematičnosti. Jsou tedy vymezeny širší oblasti problematiky, můžeme je chápat jako třídy techniky, popř. třídy technických objektů, materiálů, procesů. Následně je proveden výběr více konkrétního učiva reprezentujícího jednotlivé tř́ídy a to podle předem stanovených požadavků (zohledňujících potřeby žáka, jeho zájmy, podmínky školy atp.). Jde vlastně o způsob uplatnění exemplárního vyučování (2, s. 65-66), tedy probírá se např. jen soustružení a soustruhy (učivo) z obrábění a obráběcích strojů (trrída). Od konkrétního učiva $\mathrm{k}$ dalším zástupcům obsahu tř́ídy má být možný transfer výsledků žákova vzdělávání.

Výše uvedené tř́́dy či oblasti problematiky jsou vymezovány více způsoby, podobně jako konkretizace obsahu $\mathrm{v}$ jejich rámci. Známé je zde využití prací $H$. Wolffgramma (4), (5), pro obecně technické předměty či technickou výchovu je dobře propracovaný postup W. Furmanka a W. Walata (21, s. 51-53) - tř́́dy techniky jsou mj. vymezeny podle „vzniku a života techniky“ - rozpoznání potřeby, projektování, konstruování, programování (např. technologické zajištění výroby), vytváření, využívání a likvidace.

Otázky spojené s konkrétním obsahem, s nižším nebo vyšším zobecněním a jejich zastoupení v obsahu učiva lze spatřovat i v jiných teoriích pedagogiky, přičemž jejich aplikace je možná i v souvislostech s posouzením úplnosti 
vzdělávacího obsahu. Zde můžeme uvést Bloomovu taxonomii vzdělávacích cílů, zejména v její revidované podobě. Je v tomto smyslu návodná jak v dimenzi kognitivního procesu, tak $\mathrm{v}$ dimenzi znalostní.

V predchozích odstavcích jsme se zabývali vzdělávacím obsahem především z hlediska jeho struktury. Pojem struktura vzdělávacího obsahu, popř. struktura obsahu učiva, lze chápat jednak jako vhodnou návaznost témat a dalších součástí obsahu, viz výše, ale také v jiné dimenzi, a to na základě prací J. Brunera a publikovaných aplikací jeho výsledků (22, s. 52-86). Tento pojem lze tedy chápat i jako strukturu fakt, pojmů a generalizací ve vzájemné souvislosti těchto tří obecných kategorií. Každé vyučované téma má podle J. Brunera strukturu skládající se ze tř̀i prvků, jsou to generalizace, pojmy a fakta a přestože všechny tyto prvky jsou důležité, pro uspořádání obsahu učiva je nejvýznamnějším hlediskem pochopení generalizací. Z hlediska posouzení úplnosti vzdělávacího obsahu je tedy v souladu s uvedeným nejdůležitější posouzení učivem vytvářených generalizací a jejich „podložení fakty a pojmy“. Nastíněnou problematikou jsme se zabývali ve stati (23); generalizace představují podle nás významné principy činností $\mathrm{s}$ technikou, odpovídají zákonitostem techniky, požadavkům na správnou činnost s technikou atp.

Dosud jsme se věnovali především postupům a jejich souvislostem vedoucím k úplnosti vzdělávacího obsahu, v rámci těchto uváděných postupů jsou již kriteria posuzování úplnosti odvoditelná. Dále uvedeme vybrané př́stupy či aplikace pedagogické teorie, které mají k vymezení kriterií na posouzení úplnosti vzdělávacího obsahu přímý vliv.

Podle teorie, jejímž tvưrcem je psycholog A. Maslow, má člověk pět základních kategorií potřeb. Sestavil je od nejnižších, nejvíce naléhavých, vývojově nejstarších - fyziologických, po nejvyšší - potřeby seberealizace. Tato často publikovaná teorie je zobrazována „pyramidou“; v její základně spočívají fyziologické potřeby, odtud jejich označení nejnižší. Zde pouze naznačená teorie přistupuje k potřebám jedince systematicky i procedurálně - potřeby jedince závisejí na tom, co již má, neuspokojené potřeby ovlivňují chování, jakmile je potřeba uspokojena, objevuje se jiná atp. První čtyřri kategorie, viz tabulka 1, jsou tzv. „nedostatkové“, jejich neuspokojení vede k ohrožení biologické a psychologické existence, pátá kategorie je tzv. „růstová“, směřuje $\mathrm{k}$ překročení přítomného stavu a k nadosobním cílům (24, s. 133).

Je jen málo potřeb, při jejichž uspokojování nehrají technické prostředky významnou roli, píše W. Schlagenhauf (3, s. 10). Vyjdeme z této myšlenky, nebot' technika je skutečně považována za prostředek napomáhající uspokojování potřeb. Přesvědčíme se ale, zda je možno přímo využít teorii A. Maslowa, jak je běžně prezentována, pro posouzení úplnosti vzdělávacího obsahu. V tabulce 1 se tedy snažíme oblasti a př́klady jednotlivých kategorií potřeb rozpracovat v souladu se statí $(3$, s. 10)tak, aby souvislost $\mathrm{s}$,technickými prostředky“ byla uchopitelná.

Je nesporně myslitelné přiřadit oblast obsahu technické výchovy či téma k jedné nebo spíš více kategoriím $\mathrm{v}$ tabulce 1 a posoudit tak úplnost výuky i $\mathrm{z}$ tohoto hlediska. K více kategoriím proto, že k uspokojení potřeby může technický objekt nebo činnost přímo přispívat, ale také zvládnutí související problematiky třeba ve formě přiměřeně náročného učiva, nebo zvládnutí náročné a užitečné techniky může vést k uspokojení potřeb př́íslušných vyšším kategoriím. Použijeme-li příkladu - učivo o sociálních sítích (ICT) patří nejspíše do kategorie označené 3, dobré zvládnutí náročně zpracovaného učiva jedincem (žákem) může vést $\mathrm{k}$ vyššímu sebehodnocení a tedy $\mathrm{k}$ prínosu pro kategorie označené 4 a 5. 
Tabulka 1: Oblasti obsahu technické výchovy a jejich přiřazení do Maslowovy hierarchie potřeb

\begin{tabular}{|c|c|c|}
\hline zn. & Kategorie & Oblasti, jichž se týkají, popř. př́klady \\
\hline 1 & fyziologické potřeby & $\begin{array}{l}\text { dýchání, voda, potrava, tělesná teplota - oděv, spánek, } \\
\text { vyměšování, tělesná integrita, fyzická aktivita }\end{array}$ \\
\hline 2 & potřeby bezpečí a jistoty & $\begin{array}{l}\text { jistota zaměstnání, příjmu a přístupu ke zdrojům, právo, } \\
\text { fyzická bezpečnost, ochrana před riziky, agresí, jistota rodiny, } \\
\text { pevnost zdraví }\end{array}$ \\
\hline 3 & společenské potřeby & láska, přijetí, kruh přátel, sounáležitost a partnerství, rodina \\
\hline 4 & potřeby uznání, ocenění & $\begin{array}{l}\text { status, respekt k jiným i od jiných, sebeúcta, náklonnost, } \\
\text { uznání, úspěšnost a důvěra - spokojenost s vlastní } \\
\text { profesionalitou a možnostmi }\end{array}$ \\
\hline 5 & potřeby seberealizace & $\begin{array}{l}\text { potřeba formovat sebe, poznávat, rozvíjet individualitu a } \\
\text { schopnosti, řešení problémů, mravnost, tvořivost, spontánnost, } \\
\text { nepředpojatost, respektování faktů }\end{array}$ \\
\hline
\end{tabular}

Naše empirické zjištění:

Tabulku 1 jsme předložili desetičlenné skupině studentů navazujícího magisterského studia technická a informační výchova, spolu se širokými oblastmi vzdělávacího obsahu technických předmětů vymezených na základě práce A. Poláchové již dříve pro stat' (25). Jednalo se o tyto oblasti a př́klady: práce $\mathrm{s}$ počítačem (mj. Word atd.); práce $\mathrm{s}$ kamerou, fotoaparátem; spojovací a sdělovací technika (mobil atd.); technika pro provoz a údržbu domácnosti; elektrotechnika; stroje, prístroje, mechanická zařízení (soustruh atd.); stroje pro dopravu (auto atd.); zpracování materiálů všeho druhu (kov atd.). Požádali jsme studenty, kteří již prošli průběžnou praxí na školách, aby si představili techniku typickou pro tyto oblasti a přiřadili ji ke kategorii či kategoriím potřeb, které mohou být touto technikou a jejím zvládnutím uspokojovány. Některá přiřazení byla překvapivá, nicméně shodu mezi přiřazenými kategoriemi považujeme subjektivně za vysokou, vyšší než jsme při rozsáhlých zadaných oblastech vzdělávacího obsahu předpokládali.

$\mathrm{Na}$ základě uvedeného se domníváme, že úplnost výuky lze posoudit významem témat učiva pro možné uspokojování potřeb $\mathrm{v}$ jednotlivých kategoriích a rovněž významem zvládnutí témat $\mathrm{s}$ ohledem na způsob či náročnost jejich zpracování; komplexně pojatá výuka pokrývá všechny kategorie nebo co nejvíce kategorií členění potřeb dle A. Maslowa.

Pro posouzení úplnosti vzdělávacího obsahu lze uplatnit i hledisko více či méně rozdílných zájmů mezi dívkami a hochy, jež by výuka o technice měla přirozeně uspokojovat. Zájem totiž je charakterizován jako schopnost trvalejšího zaměření, má emoční souvislosti, stimuluje myšlení, pamět, vůli, psychické procesy (26, s. 694). Lze jej podněcovat, souvisí s životní dráhou člověka, se zkušenostmi.

Odlišné rysy a zájmy mezi hochy a dívkami vznikají podle našich nevýznamných pozorování již v raném věku, viz dále. Proto nás zaujal prístup rakouské badatelky Ch. Wächter (27). Klade otázku, proč je tak málo žen v přírodních vědách $\mathrm{a} v$ technice $\mathrm{a}$ jak se to dá změnit; při tom o odlišnost zájmů nesporně jde. $\mathrm{V}$ přednášce, na jejíž prezentaci odkazujeme, předkládá na to odpovědi související s genderovou problematikou a výchovou. Odpověd' označenou A zdůrazníme vzhledem $\mathrm{k}$ našim podmínkám, další jen doplníme vlastními poznatky. Jsou to:

A. Technické vzdělávání či technická výchova jsou zaměřovány na př́ípravu tvưrců techniky (řemeslná př́íprava, př́íprava na odborné zvládnutí), méně na užití techniky, což by zájmům i potřebám dívek více odpovídalo.

B. Ve vztahu $k$ technice je běžně mužům přisuzována rozhodující role, $\mathrm{Ch}$. Wächter napřs. hledala cliparty $\mathrm{k}$ heslu „Ingenieur" (nalezla 10x muž, 1x žena, 1x pár), k heslu „Ingenieurin“ žádný nalezený clip art. Dále na obrázcích skupiny osob pracujících či souvisejících s technikou figurovali většinou muži, žen bylo málo a zobrazení jim přisuzovala podřadnou roli. Naše zkušenosti s „obrázky free“ (pod tímto heslem se vyhledávačem zobrazila řada odkazů) jsou podobné, $v$ době vytváření DUM je třeba tuto skutečnost nepodceňovat.

$\mathrm{C}$. V němčině $\mathrm{i} v$ češtině jsou některá pracovní označení uváděna běžně $\mathrm{v}$ mužském rodě, užití v ženském rodě je nezvyklé - chemik, chirurg, technolog, zámečník, automechanik, zedník, tesař, truhláŕ aj.; naopak - zdravotní sestra, 
pečovatelka, prodavačka， sekretářka. „Ženský rod“ nevychází zrovna pozitivně ve vztahu k technickým profesím i sociálnímu statusu profesí.

D. S výše uvedeným souvisí i vytváření obrazu mužských a ženských rolí a vlastností. Muži jsou typicky prezentováni jako ochránci, bojovníci, řídící pracovníci, odborníci, podnikatelé, netypicky jsou prezentováni jako pečovatelé o dítě, o domácnost, pomáhající profese. U žen je to naopak, to dnes ani plně neodpovídá skutečnosti.

E. Ch. Wächter analyzovala katalogy hraček a v nich zobrazených dětí - chlapci byli u aut, letadel, lodí, nářadí, nástrojů, strojů, garáží, policejních a hasičských stanic a zařízení pro ně atp., dívky byly u panenek a péče o ně, dále u věcí na úklid, vaření, šití a péči o textil, byly pro ně také kosmetika, byty, domy. Adresátům hraček odpovídala i barva pozadí - modrá či růžová.

\section{Naše empirická zjištění:}

Předškolní dítě dokáže již ve věku 3,5 roku „pracovat" $s$ katalogy pro výběr hraček - v našem př́padě katalog LEGO - dítě vědělo, kde jsou v katalogu hračky pro dívky (řeklo ,hlavně vpředu“, což odpovídalo skutečnosti, přičemž tam nebyly jen hračky pro dívky, ale tam jich bylo nejvíc; dítě se tedy $\mathrm{z}$ tohoto hlediska bezpečně orientovalo) a rozlišilo $\mathrm{s}$ jistotou a opakovaně hračky ,pro kluky a pro holky“; skutečnost je taková, jak uvádí Ch. Wächter.

Položili jsme následně předem připravené dotazy 7 učitelkám působícím v preprimárním vzdělávání, dle jejich odpovědí není podporován uvedený způsob volby hraček ani složení skupin hrajících si dětí, není uvažováno při nákupech hraček s počty hochů a dívek atp. Jejich odpovědi považujeme za věrohodné, $\mathrm{k}$ tazatelům neměly učitelky žádný vztah a tazatelé dávali najevo spíš zájem o opačný výsledek. Lze proto zastávat názor, že alespoň na úrovni preprimárního vzdělávání nejsou genderové rozdíly záměrně vytvářené nebo podporované. Jde o rozdíly, které mají kořeny v soudobé kultuře, jsou tak uvědomovanou součástí naší kultury, postihovanou i malými dětmi pozorováním

Stat' vznikla jako součást řešení projektu Centrum teorie vzdělávání prrírodovědných oborů, registrační číslo CZ.1.07/2.3.00/20.0166. „dělby činností“ prováděných otcem a matkou, např̀. při zajištování chodu domácnosti. Děti předškolního věku, jichž jsme se dotazovali, bezpečně priiřazovali typické činnosti prováděné $\mathrm{v}$ rodině bud' matce, nebo otci.

Úplnost výuky lze posoudit př́nosem pro zvládání situací spojených s užitím techniky, které lze oprávněně očekávat u hochů i dívek, přičemž je třeba obezřetně přistupovat k odlišení obsahu technické výchovy podle pohlaví; nadměrným odlišením by se obsah výuky mohl stát neúplný.

\section{Závěr}

Nelze předpokládat, že v krátké době vznikne natolik ucelená teorie zabývající se úplností vzdělávacího obsahu pro technické předměty, že její dobrá aplikace by vedla k možnosti jednoznačného posouzení míry úplnosti. V předložené stati však usilujeme ukázat, že vhodnou aplikací řady teoretických přístupů, $\mathrm{z}$ nichž jsme vzhledem k rozsahu stati prezentovali jen některé, lze vymezit a aplikovat kriteria posouzení úplnosti vzdělávacího obsahu, především $\mathrm{k}$ nacházení toho, co $\mathrm{k}$ úplnosti chybí. Uvědomujeme si tedy, že např́klad pozornost při práci se vzdělávacími cíli pro technické předměty je významným činitelem, který ve stati chybí.

Oblast výuky o technice je zhlediska posouzení úplnosti vzdělávacího obsahu značně obtížná. Úplnost obsahu zde silně souvisí jak $\mathrm{s}$ učivem $\mathrm{v}$ jeho statické formě, tak s procesní stránkou výuky. Jiné než expertní posouzení dosažené míry úplnosti výuky je v praxi obtižně myslitelné. Je proto důležitý obezřetný postup tvorby vzdělávacího obsahu a jeho vhodné prezentace jako učiva a zde právě vystupuje význam kriterií, jimiž je úplnost posuzována. Stejně důležitý je potom adekvátní proces výuky.

Pokud bychom aplikovali $\mathrm{v}$ textu uvedené prístupy hodnocení úplnosti vzdělávacího obsahu na obsah a pojetí výuky technických předmětů na základní škole před 25 lety (pracovní vyučování členěné do tř́ samostatných složek - technické práce, pěstitelské práce, specifická príprava dívek), potom by byla zjevná značná neúplnost tehdejšího pojetí a rýsovaly by se i její prríčiny.

\section{Literatura}

[1] KULIČ, V. Psychologie řízeného učení. Praha: ACADEMIA, 1992. ISBN 80-200-0447-5. [2] SKALKOVÁ, J. Obecná didaktika. Praha: ISV nakl., 1999. ISBN 80-85866-33-1. 
[3] SCHLAGENHAUF, W. Inhalte technischer Bildung: Überlegungen $\mathrm{zu}$ ihrer Herkunft, Legitimation und Systematik. Technik im Unterricht, Nr. 133, S. 5-13. ISSN 0342-6254.

[4] WOLFFGRAMM, H. Allgemeine Technologie. Leipzig: VEB Fachbuchverlag, 1978.

[5] WOLFFGRAMM, H. Allgemeine Technologie. Band 1. Teil 1. Hildesheim: Verlag Franzbecker, 1994. ISBN 3-88120-241-2.

[6] KROPÁČ, J. a J. KROPÁČOVÁ Didaktická transformace pro technické předmèty. Olomouc: Univerzita Palackého, Pedagogická fakulta, 2006. ISBN 80-244-1431-7.

[7] BLÍŽKOVSKÝ, B. Úvod do systémové metodologie. In Maňák, J. (ed.) Kapitoly z metodologie pedagogiky. Brno: TEMPUS, 1996, s. 18-25. ISBN 80-210-1031-2.

[8] KROPÁC̆, J. a J. PLISCHKE Integrace výsledků vzdělávání $\mathrm{v}$ obecně technických předmětech. In XXVII. mezinárodni kolokvium o ř́zeni osvojovaciho procesu: sborník abstraktu a elektronických verzí recenzovaných príspěvkü na CD-ROMu [CD-ROM]. Brno: Univerzita obrany, 2009. ISBN 978-80-7231-650-2.

[9] PRŮCHA, J. Rámcové vzdělávací programy: problém vymezování „kompetencí žáků“. Pedagogika. 2005, roč. 55, č. 1, s. 26-36. ISSN 3330- 3815.

[10] SLAVÍK， J. a T. JANÍK Významová struktura faktu v oborových didaktikách. Pedagogika, 2005, roč. 55, č. 4, s. 336-353. ISSN 0031-3815.

[11] KVIATKOWSKI， S. M. Wprowadzanie wyników badań pedagogicznych do praktyki edukacyjnej. In Symela, K. (ed.) Wdrażanie i ewaluacja treści kstatcenia zawodowego. Tom III. Warszawa: Instytut Badań Edukacyjnych Ministerstwa Edukacji Narodowej, 1998. Ss. 1320. ISBN 83-87925-01-2.

[12] JERUSZKA， U. Uwarunkowania prawnoorganizacyjne wdrażania i ewaluacji nowych programów nauczania - stan aktualny i kierunki zmian. In Symela, K. (ed.) Wdrażanie i ewaluacja treści kstatcenia zawodowego. Tom III. Warszawa: Instytut Badań Edukacyjnych Ministerstwa Edukacji Narodowej, 1998. Ss. 2138. ISBN 83-87925-01-2.

[13] HENDL， J. Kvalitativni výzkum: základni metody a aplikace. Praha: Portál, 2005. ISBN 807367-040-24.

[14] NEZVALOVÁ. D. Kvalita ve škole. Olomouc: Univerzita Palackého, Pedagogická fakulta, 2002. ISBN 80-244-0452-4.

[15] KROPÁČ, J. a M. CHRÁSKA Výchova $v$ obecně technických předmětech. Olomouc: Univerzita Palackého, Pedagogická fakulta, 2004. ISBN 80-244-0897-X.

[16] KRUŠPÁN， I. Rozvíjanie technického tvorivého myslenia $\mathrm{v}$ procese technickej záujmovej činnosti. In Rozvijanie tvorivých činností v pracovnej výchove. Banská Bystrica: Pedagogická fakulta, 1985, s. $47-58$.

[17] ŠTOFA， J. O všeobecnej technickej vzdelanosti mládeže. In Technické vzdelanie jako súčast' všeobecného vzdelania. Banská Bystrica: Pedagogická fakulta, 1992, s. 30 - 33. ISBN 8085162-37-7.

[18] RIEDL, A. Didaktik II - Berufliche Bildung [online]. München: Technische Universität, 2003. [cit. 2004-11-15]. Dř́ive dostupné na WWW: <http://www.paed.ws.tum.de/>.

[19] HEJNÝ, M. a F. KUŘINA Tři světy Karla Poppera a vzdělávací proces. Pedagogika, 2000, roč. 50, č. 1, s. 38-50. ISSN 3330-3815.

[20] ŠTECH, S. Zřetel k učivu a problém dvou modelů kurikula. Pedagogika, 2009, roč. 59, č. 2, s. 105-115. ISSN 0031-3815.

[21] FURMANEK, W. a W. WALAT Przewodnik metodyczny dla nauczycieli technikiinformatyki. Rzeszów: Wydawnictwo Oświatowe FOSZE, 2002. ISBN 83-88845-08-X.

[22] PASCH, M. aj. Od vzdělávacího programu $k$ vyučovaci hodině. Praha: Portál, 1998. ISBN 80-7178-127-4.

[23] KROPÁĆ, J. st., J. KROPÁČ ml. a J. PLISCHKE Ke struktuře obsahu učiva technických předmětů $\mathrm{v}$ základním vzdělávání generalizace. Journal of Technology and Information Education. 2009, Olomouc - EU, Univerzita Palackého, ročník 1, číslo 3, s. 17 23. ISSN 1803-537X (print). ISSN 1803-6805 (on-line).

[24] ČÁP, J. a J. MAREŠ Psychologie pro učitele. Praha: Portál, 2001. ISBN 80-7178-463$\mathrm{X}$.

[25] KLEMENT, M., J. KROPÁC̆ a A. ZUBATÁ Uplatnění kritického myšlení žáka ve výuce o technice a informačních a komunikačních technologiích. In Technológie vzdelávania v príprave učitelov prírodovedných a technických predmetov. Prešov: Katedra fyziky, matematiky a techniky, FHPV PU v Prešove a Katedra prírodovedných a technických disciplín PF PU v Prešove, 2011, s. 171-177. ISBN 97880-555-0438-4.

[26] HARTL, P. a H. HARTLOVÁ Psychologický slovník. Praha: Portál, 2000. ISBN 80-7178-303-X.

[27] WÄCHTER, Ch. Grenzüberschreitungen: 
TechnikbildungundVorstellungen von Technik undNaturwissenschaften - ein (Gender-) Blick

\section{Kontaktní adresa:}

Jitka Plischke, PhDr., Ph.D.,

Ústav pedagogiky a sociálních studií,

Pedagogická fakulta UP, Žižkovo nám. 5, 771

40 Olomouc, ČR, tel. 00420585635 173, e-

mail: jitka.plischke@upol.cz nach Europa. Dostupné na WWW:

<http://www.acatech.de/?id=886>.

Jiří Kropáč, Doc. PaedDr., CSc.,

Katedra technické a informační výchovy,

Pedagogická fakulta UP, Žižkovo nám. 5, 771

40 Olomouc, ČR, tel. 00420585635805 , e-

mail: jiri.kropac@upol.cz 